\title{
TAX DELINQUENCY OF RURAL REAL ESTATE
}

\author{
DONALD JACRSON*
}

Tax delinquency of rural real estate has presented an increasingly serious problem since I928, though, in fact, a gradual increase in the extent of the problem had been occurring before that year. For selected counties (towns in New England) throughout the country the area of land delinquent has nearly trebled since I928 according to tabulations and estimates by the Bureau of Agricultural Economics of the United States Department of Agriculture. ${ }^{1}$

The acreage and the amount of taxes delinquent on the levies of 1928 -1932 are shown by geographic divisions in the following table. These figures represent the total delinquency of rural real estate on each levy and do not distinguish between those delinquent in only one year and those repeatedly delinquent. In many cases the taxes reported delinquent were paid soon after the delinquency date.

Total Delinquency of Rural Real Estate Taxes in Selected Counties, LeVIES OF I928-I932

\begin{tabular}{|c|c|c|c|c|c|c|c|c|c|c|c|c|}
\hline \multirow{2}{*}{$\begin{array}{c}\text { Geographic } \\
\text { Region }\end{array}$} & \multirow{2}{*}{$\begin{array}{c}\text { Total } \\
\text { Counties } \\
\text { in } \\
\text { Region }\end{array}$} & \multirow{2}{*}{$\begin{array}{c}\text { Counties } \\
\text { Included } \\
\text { in } \\
\text { Table }\end{array}$} & \multicolumn{2}{|c|}{1928} & \multicolumn{2}{|c|}{1929} & \multicolumn{2}{|c|}{1930} & \multicolumn{2}{|c|}{1931} & \multicolumn{2}{|c|}{1932} \\
\hline & & & Acres * & Taxes & Acres & Taxes * & Acres & Taxes & Acres & Taxes * & Acres & Taxes \\
\hline $\begin{array}{l}\text { New England..... } \\
\text { Middle Atlantic... } \\
\text { East North Central } \\
\text { West North Central } \\
\text { South Atlantic.... } \\
\text { East South Central } \\
\text { West South Central } \\
\text { Mountain.......... } \\
\text { Pacific... . . . . . . }\end{array}$ & \begin{tabular}{|c|} 
Number \\
$2,008:$ \\
150 \\
436 \\
621 \\
553 \\
364 \\
470 \\
277 \\
133
\end{tabular} & \begin{tabular}{|c|} 
Number \\
5131 \\
46 \\
68 \\
115 \\
109 \\
123 \\
95 \\
62 \\
31
\end{tabular} & $\begin{array}{r}694 \\
1,188 \\
2,234 \\
11,372 \\
5,183 \\
4,842 \\
4,489 \\
7,584 \\
1,847\end{array}$ & \begin{tabular}{|r}
852 \\
948 \\
1,114 \\
4,198 \\
1,834 \\
1,281 \\
1,300 \\
1,656 \\
872
\end{tabular} & $\begin{array}{r}773 \\
1,381 \\
2,657 \\
13,116 \\
6,000 \\
5,161 \\
5,380 \\
8,556 \\
2,651\end{array}$ & $\begin{array}{r}81,087 \\
1,112 \\
1,400 \\
5,193 \\
2,103 \\
1,361 \\
1,615 \\
1,888 \\
1,153\end{array}$ & $\begin{array}{r}927 \\
1,577 \\
3,444 \\
16,937 \\
7,978 \\
7,979 \\
10,156 \\
11,235 \\
4,989\end{array}$ & $\begin{array}{r}81,316 \\
1,327 \\
1,954 \\
6,765 \\
2,645 \\
2,172 \\
2,737 \\
-2,369 \\
2,259 \\
\end{array}$ & $\begin{array}{r}1,220 \\
2,366 \\
4,894 \\
23,622 \\
10,716 \\
10,993 \\
15,419 \\
16,192 \\
7,402\end{array}$ & $\begin{array}{l}1,748 \\
1,974 \\
2,828 \\
8,989 \\
3,297 \\
2,743 \\
3,832 \\
3,226 \\
3,273\end{array}$ & $\begin{array}{r}1,500 \\
3,532 \\
5,859 \\
25,877 \\
12,632 \\
12,570 \\
19,255 \\
19,318 \\
8,911\end{array}$ & $\begin{array}{r}8,152 \\
2,792 \\
2,776 \\
8,603 \\
3,108 \\
3,017 \\
3,732 \\
3,897 \\
3,865\end{array}$ \\
\hline United States. . & $\ldots$ & .. & 39,437 & 14,159 & 45,679 & 16,916 & 65,227 & 23,549 & 92,828 & 31,914 & 109,458 & 34,247 \\
\hline
\end{tabular}
the data to thousands, any excess over the figures stated was disregarded.

- S.B., 1920, M.B.A., 1921, Northwestern University; M.A., 1925, Harvard University; also attended Stanford, California, Cornell, and Wisconsin Universities. Bureau of Agricultural Economics. U. S. Department of Agriculture, I923-I924, in history and statistics, and, since I931, in agricultural taxation. Joint author of The Farmers' Tax Problem, House Doc. 406; author of reports and articles on farm and tax delinquency. Planned and participated in survey of rural tax delinquency, described in note $\mathbf{I}$, infra. Supervisor of operation of the current Federal Works Progress Administration Project, administered by the Bureau, to collect and tabulate data on farm mortgage debts, farm land transfers, and farm taxes in $x, 000$ counties in 18 states.

${ }^{1}$ Administering 2 Civil Works Administration Project in 1932-1933, the Bureau of Agricultural Economics collected dat2 on rural real estate tax delinquency for the levies of r928-1932. Data were obtained for about two-thirds of the counties in the country, and for about one-fourth of the counties the data were tubulated in detail. 
The number of tax certificates, or tax liens, sold has increased more rapidly than has delinquency, but they have been sold against a relatively small portion of the delinquent acreage. The tax deeds given, that is actual transfers of title resulting from tax delinquency, are very few in number. In cases where private buyers purchase tax liens the taxing jurisdictions obtain their money but the owners of the land are not relieved of their obligation. In other cases the state or the county has acquired tax liens or simply carried the delinquent taxes as an "open account," and has so far failed to collect the tax. The area consequently left subject to tax liens held by taxing jurisdictions has increased more rapidly than has the total area delinquent. The subject thus involves two distinct problems, that of the taxing jurisdiction in collecting tax revenues, and that of the farmer in trying to pay his taxes (current and delinquent) and free his real estate of tax debt. The taxing jurisdictions have been more interested in obtaining revenue than in taking tax liens or acquiring extensive real estate holdings. Their attention consequently has been centered on the problem of collection. Land owners, caught in the economic maelstrom, have been searching for methods of avoiding heavy penalties or the loss of their property. They have voted for reductions in expenditures and for shifts in the distribution of tax levies; they have begged for leniency; and in scattered instances apparently they have conspired to prevent tax collections.

State legislatures have had to face the resulting problems. Though governmental expenditures can be reduced to some extent, they are in large part necessary-made so by the citizens' demands for governmental services. The legislatures must find ways to collect taxes, but taxes can be collected only from those with means to pay them. Adequate understanding of the problem of tax delinquency requires the taking of this fundamental legislative view of availability of tax money for governmental revenues, and this is the principal point to be emphasized in the brief discussion below.

The tax delinquency problem is in a very real sense as broad and intricate as the subject of public finance. Its understanding, and to some extent its solution, has suffered from unwarranted simplification in its treatment. There has been pretty generally a failure to analyze the problem adequately. The first appearance or evidence of delinquency is failure to collect revenue, and a tendency has developed to look upon delinquency purely as a problem for the tax collector. In the last analysis this attitude assumes that all tax delinquency is voluntary. Even in these recent years of wholesale delinquency, various academic and governmental bodies considering the matter of tax revenues have prescribed greater severity of penalties, higher interest rates, and stricter administration of collection laws as the appropriate correctives for the situation. This is what may be termed the tax collector's view point. The tax collector is given no discretion, and should be given none, as to his essential duties. Obviously it is a legislative function, supplemented by executive and administrative regulations, to prescribe the manner and amounts in which taxes shall 
be levied since it encompasses consideration of the whole body of government. The tax system must be developed as an integral part of the organization of governmental service. In sound planning each service established must be based upon a visible source of revenue. Services cannot be permanently given without such revenue. The fundamental problem of the tax system then becomes that of spreading a levy or group of levies over the property, income and privileges of the community in such a manner as to produce revenue equal to the total cost of services furnished to society through the governmental units.

It is not the place of the assessor or tax collector to question the taxation which is imposed. The situation is parallel to that of private debts. Assuming that the private debtor is solvent, it is the business of the collection agent to use every legitimate means in pressing for collection. It is a patent fact that many private debtors and many "taxpayers" will delay or avoid payment if possible. It is no less patent that many persons who, by industry and good management could pay their debts and their taxes, will fail to do so. Some members of this latter class are so incompetent that delinquency and insolvency will finally eliminate them from the debtor class and the taxpaying class. Many, however, can with economic or social pressure be encouraged to meet their obligations. In these latter instances considerable pressure undoubtedly is justifiable.

In no small part an overemphasis of the tax collection job has led to a biased interpretation of the tax delinquency problem as a whole. Several factors have combined to this end. In a broad and general way the opposition and clash of economic interests may be held largely responsible. Legislatures probably must of necessity partially represent economic interests, as opposed to those of individuals; and tax levies are distributed accordingly. In legislation, however, tax delinquency is only potential, whereas in the administration of the tax laws it becomes actual. The problem thus presents itself to the collector in a far more direct and forceful manner than it does to the legislature.

It is in many cases absolutely impossible to define a point or level at which failure to pay a debt or a tax bill ceases to be voluntary and becomes an economic necessity. This is particularly true with low-income groups. The farmer, the small business man, the small home owner, commonly varies his expenditures in consumption, depending upon his total income. With the farmer the terms "net income" and "profits" are arbitrary or ambiguous. Out of his gross receipts he must meet direct business charges, overhead and consumption costs. During the depth of the depression years following 1929, the income avaflable to farmers for accustomed consumption purposes fell close to zero. In numerous cases, of course, the net actually became a negative. Only by lowering his standard of living radically could such a farmer pay his business costs and his debts. His ability to pay taxes became contingent upon his ability and willingness to lower the consumption standards of his family or to delay payment of private debts. He frequently was forced to choose 
between tax delinquency, business insolvency or painful deprivation for his family.

It becomes apparent when these facts are considered that tax delinquency cannot be considered as usually-voluntary, and the development of delinquency during the past decade bears out this interpretation. The increased delinquency which has come about has accompanied economic distress. It has grown with adverse changes in the taxpayer's economic situation, not with changes in tax laws. It is true that the administration of tax laws has changed to some extent during this period. The nature of the changes has been so varied, however, that it is impossible at the present time to classify their effects upon tax collections. In some communities pressure upon the taxpayer has been increased on the assumption that he could pay if he would; in others pressure has been lessened on the assumption that many taxpayers were in an impossible economic situation and could not pay.

The typical property owner's view point, of course, has been quite opposite to that of the tax collector and fiscal officer. He has assumed that delinquency is a necessary consequence of the economic conditions which have prevailed. In many cases he has lowered his standard of living, redoubled his efforts to produce greater income, and still has found himself unable to meet his tax bills and his private debts.

Of course, taxes or debts can be paid with borrowed money, but this assumption often has counted for too much in the consideration of tax problems. It is, in general, during hard times that income is insufficient to meet costs. These are the same times in which it is most difficult to renew loans or to borrow for tax purposes. In this regard also the property tax offers a far more difficult problem than does the income tax. Both the amount of the tax levy and the ability to borrow for tax purposes are related to the value of the property. Most of the time the value of a specific piece of property is hypothetical. Even academic agreement on an acceptable definition of value is difficult to attain, and when attained it still is academic. Only occasionally is the sale value of a given property actually known. Even then, it is only in a narrow sense that we can assume the exchange price to be a good representation of "true" value as defined in the economics text books. An unwise buyer or an unwise seller may produce a sale-value figure quite at variance with that which would theoretically result from the bid and offer of a marginal buyer and a marginal seller in an open market. Furthermore, sale value would apply only at the moment of sale.

Determination of value by the capitalization of net income is quite a different matter. It can not apply as at a given moment. It must be an average or net result for some specific accounting period. The choice of this period is purely an arbitrary matter. There undoubtedly are many farmers for whom net income during the depression years was a very slight fraction of their average for the preceding decade.

What value is an equitable one on which to levy taxes? If it is sale value many properties should have paid no taxes during the years I93r and x932. And, of course, sale value will always be out of date except for a relatively small number of propertic: 
which have recently changed hands. If it is the value resulting from capitalization of income, the appropriate tax levy will depend entirely upon the period chosen over which to determine average value.

This difficulty with the meaning of "value" is one important reason why the work of the tax assessor presents such difficulties, and is so unsatisfactory in individual instances. The philosophers can not agree, and so they turn the practical problem over to the assessor, who normally has no special training in the subject of values, but who presumably is assumed in his community to have good common sense. And assessment is vitally linked to delinquency.

If one studies the assessment of individual properties in the average community he will be impressed with the apparent irregularities and injustices involved. If he studies it still more carefully, however, he is likely to be impressed with the fact that the assessor has done a very good job, considering the system and conditions under which he works. Related to the best scientific estimates available for true values, assessed values in a given community may be found to vary from as low as I per cent to as high as several hundred per cent. This comparison, when true, indicates great injustice in the resulting property taxation. Much of the reason must be admitted, however, to lie in the variations in size, type, physical quality, location and other internal and environmental factors, the significance of which the assessor is not prepared to appraise.

A recent report on the tax system of the State of Maine objects to making assessments of rural property in the early spring. It is stated that the assessor can not make a proper assessment when the land is littered with snow or the "debris" remaining from the previous winter. The opinion is ventured here that in the problem of the assessor of rural lands, snow and debris are insignificant in comparison with some of the value problems on which the economists themselves are unable to agree. A similar tax report complains of the deficient ability of the general run of tax assessors. At the same time it suggests for the assessor's use visual correlation processes which even for the accomplished statistician are indefinite and which for the uninitiated are a sheer mystery.

Thus in its nature tax delinquency of real estate is of these two general classes: (1) voluntary or wilful, and (2) economic or necessary. Individual instances of the two are intermingled in an unpredictable way. Sure classification of any one case would require a laborious, scientific analysis. Economic or necessary delinquency has occurred extensively. Even during the two decades before I928 tax delinquency of rural real estate was increasing. Since 1928, it has increased in most states many fold. Not only has the area increased, but on the average the amount of unpaid delinquency per acre also has increased as unpaid levies have continued to accumulate.

The real problems of extensive delinquencies are beyond the collector and the assessor; they lie in the field of sociology and economics, and directly within the function of the legislature in its choice of bases of tax payments. It is well known 
that much voluntary delinquency exists (even conspiratory delinquency in the form of tax strikes probably exists in scattered instances) and yet it is so intermingled with economic or necessary delinquency that the problem can not be treated as resulting solely from a perverse attitude on the part of taxpayers.

There are assessment problems and conflicts of interests which must be considered. For instance, it apparently is commonly accepted that delinquency rormally will appear first and most frequently on low-value properties. But wherein lies the normality of this? It is a truism that with perfect assessment low-value properties are no more likely to become delinquent than are highly valued properties. It is a truism because theoretically taxes are assessed according to ralue, and value depends upon income either directly or indirectly through sale value which in turn will, in the long run, reflect anticipated income. Delinquency upon any one class or quality of real estate is a reflection upon the justice of the assessment system.

A more fundamental problem is the establishment of a tax system which will properly distribute the tax burden according to benefits received or ability to pay. The assumption here is that in general the distribution must be according to ability to pay or at least not beyond such ability. This point unquestionably is open to argument, but it will not be argued here as the main object is to indicate limits that affect tax delinquency rather than methods of distribution. In either case society as a whole must be considered, and it does seem apparent that certain members of society must be served by society collectively-that is, by government-beyond their ability to contribute. The total tax base must include the two general classes of ability represented by property and by income. In a homogeneous community either property or income alone might represent an appropriate tax base, but with the multitudinous varieties of economic activity today so easy a solution is impracticable. The less arbitrary the distribution of levies over the total ability of society, of course, the better, but the final decision almost certainly must be arbitrary because thus far the facts concerned have been too intricate for complete analysis.

The principal point to be made here is only that extensive delinquency of taxes, if that delinquency is economic, indicates a maladjustment in the underlying system. The tax collector can obtain payment only where means of payment exist. Beyond that point he is butting against a wall. It is through a readjustment in the levies, and only through that course, that economic and necessary delinquency can be reduced to a minimum.

Farm or rural properties quite usually carry lower tax rates than do urban properties. This can not be taken, however, as proof that farms are lightly taxed relative to other classes. Real estate is easy for the assessor to find, and taxes on real estate are relatively difficult to avoid. Many other types of tax paying ability do escape the assessor and the tax collector. Farmers and small home owners, as a class, have an exceptionally large proportion of their wealth invested in real estate, 
and there seems no question that this fart more than offsets any rate differential in their favor.

An aspect of rural real estate delinquency which has become of particular importance in very recent years is that connected with land use. Does tax delinquency indicate an unfortunate use of the land? If the delinquency is voluntary it surely does not. If the delinquency is necessary or economic it still may be the result of maladjustment in assessments or in the underlying tax system.

When collection of delinquent taxes is forced by means of tax sales and consequent transfer of the land to "stronger hands," the taxing jurisdiction obtains its revenue, but the owner is dispossessed. Whether or not the land is transferred to hands which really are stronger, that is, to hands capable of obtaining from it a greater income, often is questionable. Where the delinquency results from unfortunate management the transfer may theoretically be justified. Where the delinquency results from a badly adjusted system or from general economic conditions, such as those of a general economic depression, such transfer is a questionable expedient either for obtaining immediate revenue or for improving land use.

The above discussion of delinquency of rural real estate settles few, if any, of the vital questions involved. The problem is far too intricate and difficult for such easy solution. One of the difficulties in its analysis in the past has been that the whole problem has been assumed simple, whereas it is as intricate as the whole system of government service and government revenues. The collection syster $\Omega$ can be greatly improved. Administration of the laws can be strengthened, but to do only that fails to get at the root of the social and economic problems involved. A good collection system and generally good administration can not correct a malformed tax system that fails to recognize the very low levels to which certain incomes and sources of funds fall in adverse economic periods. Any one cause which can rightfully be assigned for tax delinquency must be so general and so inclusive as to be entirely meaningless. One might as well attempt to assign a single cause for failure to meet private debts.

Tax delinquency is failure to pay taxes. Why does one fail to pay his debts, including taxes? The answer is interwoven through the whole subject of credit, or of public finance. Increased severity of collection procedure undoubtedly can be made to reduce voluntary delinquency, but it becomes apparent upon analysis that only through revision of the underlying tax system itself, to lighten the burden on real estate, can "economic" delinquency of rural real estate be reduced to reasonable proportions. 